\title{
Formation of prothrombin converting activity
}

Citation for published version (APA):

Hemker, H. C., Esnouf, M. P., Hemker, P. W., Swart, A. C. W., \& MacFarlane, R. G. (1967). Formation of prothrombin converting activity. Nature, 215(5098), 248-251. https://doi.org/10.1038/215248a0

Document status and date:

Published: 01/01/1967

DOI:

10.1038/215248a0

Document Version:

Version created as part of publication process; publisher's layout

\section{Please check the document version of this publication:}

- A submitted manuscript is the version of the article upon submission and before peer-review. There can be important differences between the submitted version and the official published version of record.

People interested in the research are advised to contact the author for the final version of the publication, or visit the DOI to the publisher's website.

- The final author version and the galley proof are versions of the publication after peer review.

- The final published version features the final layout of the paper including the volume, issue and page numbers.

Link to publication

\footnotetext{
General rights rights.

- You may freely distribute the URL identifying the publication in the public portal. please follow below link for the End User Agreement:

www.umlib.nl/taverne-license

Take down policy

If you believe that this document breaches copyright please contact us at:

repository@maastrichtuniversity.nl

providing details and we will investigate your claim.
}

Copyright and moral rights for the publications made accessible in the public portal are retained by the authors and/or other copyright owners and it is a condition of accessing publications that users recognise and abide by the legal requirements associated with these

- Users may download and print one copy of any publication from the public portal for the purpose of private study or research.

- You may not further distribute the material or use it for any profit-making activity or commercial gain

If the publication is distributed under the terms of Article $25 \mathrm{fa}$ of the Dutch Copyright Act, indicated by the "Taverne" license above, 


\section{Formation of Prothrombin Converting Activity}

After measurement of the conversion of prothrombin to thrombin in a purified system, a model has been constructed for the kinetics of the formation of prothrombin converting activity. In the model phospholipid provides a surface on to which coagulant factors bind.

by

H. C. HEMKER, M. P. ESNOUF, P. W. HEMKER, A. C. W. SWART and R. G. MACFARLANE

Nuffield Department of Clinical Biochemistry, Radcliffe Infirmary, Oxford;

Laboratory of Coagulation Biochemistry Hematology Section, Department of Internal Medicine, University Hospital, Leyden

IN blood coagulation prothrombin is converted to thrombin as the result of the interaction of several blood coagulation factors ${ }^{1,2}$. One of the features of blood coagulation theory, which is still controversial, is the precise identity of the prothrombin converting activity. While most authors agree that conversion of prothrombin requires the presence of activated factor $\mathrm{X}$ (factor $\mathrm{X}_{\mathrm{a}}$ ), factor $\mathrm{V}$, phospholipid and calcium ions, the form of their interaction is still in debate. Some authors suggest that the final prothrombin converting substance is a form of factor $\mathrm{V}$ modified by its interaction with factor $\mathrm{X}_{\mathrm{a}}$ (ref. 3), while others hold the view that factor $\mathrm{V}$ facilitates the enzyme conversion of prothrombin to thrombin by factor $\mathrm{X}_{\mathrm{a}}$ (ref. 4). The function of the phospholipid in this system seems to depend on its providing a suitable surface on which this reaction may take place, rather than to any specific chemical constitution ${ }^{4}$.

We describe here experiments performed with purified reagents, in which the kinetics of prothrombin activation have been investigated with a view to elucidating further the nature of the process.

Bovine prothrombin was prepared and given by $\mathrm{Dr} K$. Denson $^{5}$. The preparation contained $10,000 \mathrm{NIH} \mathrm{V} / \mathrm{ml}$. of prothrombin, and less than 10 per cent of contaminating material that had neither coagulant nor inhibitory activity. Bovine factor $V$ was prepared according to Esnouf and Jobin $^{6}$; the stock solution contained $40,000 \mathrm{U} / \mathrm{ml}$. and had 
no detectable contamination. Factor $\mathrm{X}_{\mathrm{a}}$ was prepared by the conversion of factor $X$ (ref. 7) by the coagulant protein from Russell's viper venom ${ }^{8}$, and then separating the venom protein from factor $\mathrm{X}_{\mathrm{a}}$ by chromatography ${ }^{4}$. Factor $\mathrm{X}_{\mathrm{a}}$ was not contaminated with any other clotting factors.

The phospholipid was a commercial preparation of mixed phospholipids, 'Inosithin'. Emulsions of this phospholipid were prepared as described by Jobin and Esnouf ${ }^{4}$.

The experiments were carried out as follows. Phospholipid, factor $\mathrm{X}_{\mathrm{a}}$ and factor $\mathrm{V}$ were added together to the final concentration desired in a medium containing 12 mmolar calcium chloride and $40 \mathrm{mmolar}$ tris-hydrochloric acid buffer, $p H \mathbf{H} \cdot \mathbf{5}$. The mixture thus obtained was called the "first incubation mixture". It was kept at $37^{\circ} \mathrm{C}$ during the "first incubation time". Except in the experiments shown in Fig. 1 where it is plotted along the abscissa, this time was always $4-6 \mathrm{~min}$. After this the first incubation mixture was put in an ice bath at $0^{\circ} \mathrm{C}$ which prevented appreciable decay of prothrombin converting activity for at loast $30 \mathrm{~min}$.

To $1.8 \mathrm{ml}$. of this "first incubation mixture" $0.2 \mathrm{ml}$. of the prothrombin solution was added at zero time of the second incubation. The concentration of prothrombin in the second incubation was thus $1,000 \mathrm{NIH} \mathrm{U} / \mathrm{ml}$; this concentration represents an excess of substrate for the prothrombin activator, and did not seem to be inhibitory.

From the second incubation mixture $0.1 \mathrm{ml}$. portions were sub-sampled into $0.1 \mathrm{ml}$. of fibrinogen solution of $100 \mathrm{mg} / \mathrm{ml}$. (human fibrinogen Kabi). The clotting time of this mixture was measured in a water bath at $37^{\circ} \mathrm{C}$. The clotting times thus obtained were converted into concentrations of thrombin by comparison with the clotting times obtained by dilutions of a standard thrombin solution, in comparable conditions of $p H$, ionic strength, calcium ion concentration and temperature.

The amount of thrombin thus found was plotted against the incubation time in the second incubation mixture, and from this graph the initial velocity of thrombin formation induced by the prothrombin activator was estimated.

A representative experiment is shown in Fig. 1. In this experiment a mixture with high prothrombin converting activity was diluted 1 in 3 and 2 in 3 , and thrombin generation has been followed in the original sample as well as in the dilutions. The two lower lines in the graph are drawn at $2 / 3$ and $1 / 3$ of the slope of the steepest line. It can be seen that: $(a)$ the thrombin generation curve cannot be distinguished from a straight line in the initial phase; $(b)$ the initial velocity of thrombin generation can be regarded as proportional to the amount of prothrombin 


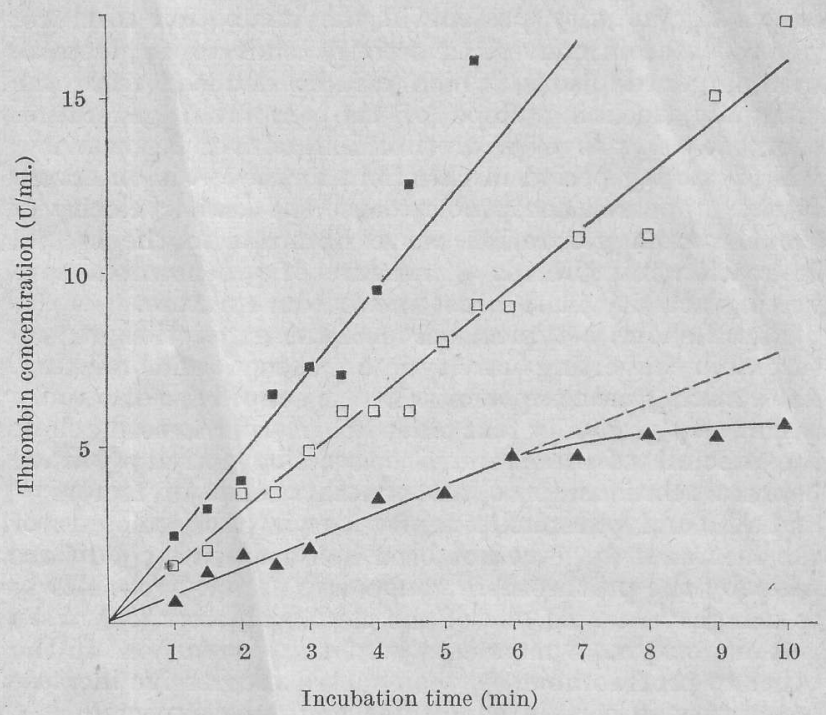

Fig. 1. Thrombin generation in a mixture containing prothrombin and prothrombinase activity. (다- Thrombin generation in a mixture containing $20 \mathrm{~J} / \mathrm{ml}$. of factor $\mathrm{V}, 8 \mathrm{U} / \mathrm{ml}$. of factor $\mathrm{X}_{\mathrm{a}}, 4 \gamma / \mathrm{ml}$. of phospholipid, $1,000 \mathrm{NIH} \mathrm{v} / \mathrm{ml}$. of prothrombin, $12 \mathrm{mmolar}$ of calcium chloride, and 40 mmolar tris hydrochloric acid buffer, $p \mathrm{H} \mathrm{7.5}$, ( $\square-\square)$ Thrombin generation in the same mixture immediately after a 2 in 3 dilution with $40 \mathrm{mmolar}$ tris-hydrochloric acid buffer, $p$ H 7.5 containing 12 mmolar calcium chloride. ( $\mathbf{A}$ - $)$ The same immediately after a 1 in 3 dilution.

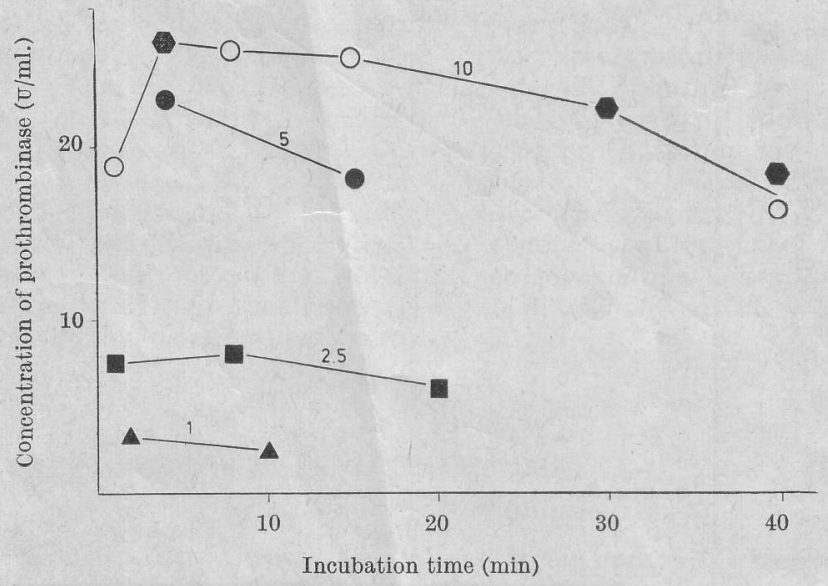

Fig. 2. Generation of prothrombinase activity in a mixture containing factor $V$, factor $X_{a}$ and phospholipid. The final concentrations were $25 \mathrm{~J} / \mathrm{ml}$. of factor $\mathrm{V}, 10,5,2.5$ or $1 \mathrm{U} / \mathrm{ml}$. of factor $X_{\mathrm{a}}$ (as indicated), $5 \gamma / \mathrm{ml}$. of phospholipid, $12 \mathrm{mmolar}$ ealcium chloride, and $40 \mathrm{mmolar}$ tris-hydrochloric acid buffer, $p H \mathbf{H} 7 \cdot 5$. The concentration of prothrombinase is expressed in arbitrary units, one unit being defined as the amount that causes a velocity of thrombin generation of $1 \mathrm{NIH}$ U/10 min during the second incubation. 
converting activity present in the incubation mixture; (c) prothrombin converting activity tends to be unstable with larger dilutions, which can be deduced from the gradually declining slope of the thrombin generation curve at a low level of prothrombin converting activity; and (d) no lag period in thrombin formation is observed. It thus appeared acceptable to use the initial velocity of the thrombin generation curve obtained in the second incubation mixture, as a measure of prothrombin converting activity in the first incubation mixture.

Fig. 2 shows a typical curve of the generation of prothrombin converting activity in a first incubation mixture. After mixing the components there is a rapid rise of activity which very gradually falls off again. As will be seen below, the amount of prothrombin converting activity formed bears a relationship to the concentrations of factors $\mathrm{V}$ and $\mathrm{X}_{2}$, and phospholipid. By varying the amounts of the reactants we have not been able to create conditions whereby the prothrombin converting activity rose slowly to a high value. If one of the clotting factors $\left(\mathrm{X}_{\mathrm{a}}\right.$ or $\left.\mathrm{V}\right)$ was an enzyme which catalysed the conversion of the other to prothrombinase, then such a progressive increase in activity in certain conditions might be expected.

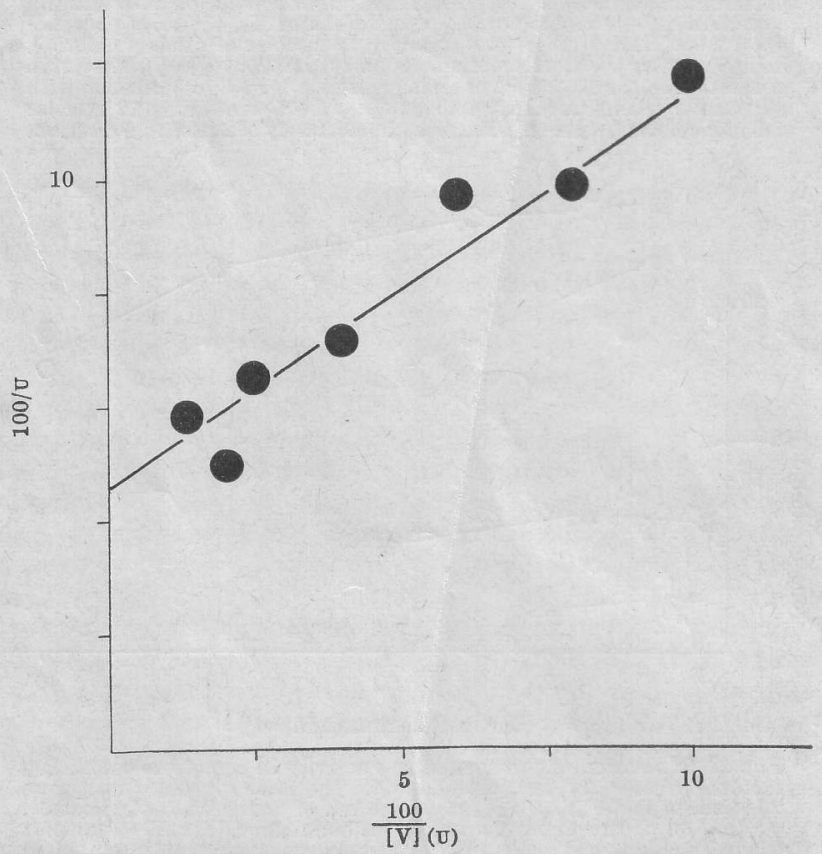

Fig. 3. Relation between concentration of factor $\mathrm{V}$ and prothrombinase activity. The inverse of the concentration of factor $V$ expressed in $U$ is plotted against the inverse of the prothrombinase activity expressed in $\mathrm{U}$. 
At relatively large concentrations (causing a velocity of thrombin formation of $\sim 20$ NIH $\mathrm{U}$ of thrombin $/ \mathrm{ml} . / 10$ $\mathrm{min})$, the half-life time of the prothrombin converting activity was estimated to be about $55 \mathrm{~min}$; the half-life time of the prothrombin converting activity generated in a thrombin generation test (that is, in a system using normal plasma) was estimated to be about $10 \mathrm{~min}$ in the same conditions. Thus the prothrombin converting activity appeared to be more stable in its purified form than it is in plasma. This again emphasizes the point that an inhibitor of prothrombin conversion is likely to be present in plasma ${ }^{9}$.

Figs. 3, 4 and 5 show that a linear relationship between the reciprocal of the concentration of either of the reactants and the reciprocal of the final prothrombin converting activity is the simplest kind of relationship that can be deduced from these experiments. Essentially the same results were obtained when the amount of thrombin was estimated spectrophotometrically as $n$-benzoyl arginine methyl esterase activity.

This relationship cannot be accounted for by the reaction scheme of the type

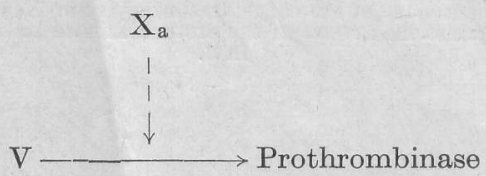

or by any of its modifications. It can, however, be accounted for by a model based on the assumptions that: (a) there are a fixed number of factor $\mathrm{X}_{\mathrm{a}}$ binding sites and a fixed number of factor $V$ binding sites on each unit phospholipid micelle surface; (b) prothrombin conversion occurs when a factor $X_{a}$ molecule and a factor $V$ molecule, bound to the phospholipid surface, are in a favourable position one to the other; (c) binding of one of the factors does not influence the binding characteristics of the other one ${ }^{5}$. This model can be written in the following reaction formulae

$$
\begin{gathered}
P+\mathrm{V} \rightleftharpoons P \sim \mathrm{V} \\
P+\mathrm{X}_{\mathrm{a}} \rightleftharpoons P \sim \mathrm{X}_{\mathrm{a}} \\
P \sim \mathrm{V}+\mathrm{X}_{\mathrm{a}} \rightleftharpoons \text { Prothrombinase } \\
P \sim \mathrm{X}_{\mathrm{a}}+\mathrm{V} \rightleftharpoons \text { Prothrombinase }
\end{gathered}
$$

The word prothrombinase refers to the complex which converts prothrombin to thrombin.

With these assumptions the following relationships will exist: (a) the concentration of prothrombinase is proportional to the number of bound factor $\mathrm{X}_{\mathrm{a}}$ molecules/ unit of phospholipid surface as well as to the amount of bound factor V molecules per unit of phospholipid surface; 


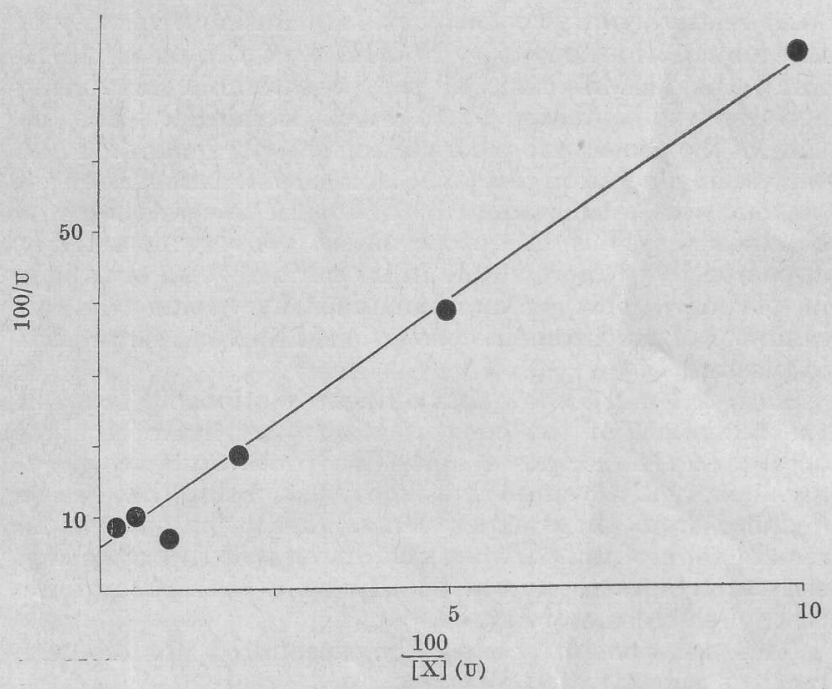

Fig. 4. Relation between concentration of factor $\mathrm{X}_{\mathrm{z}}$ and prothrombinase activity. The inverse of the concentration of factor $\mathrm{X}_{\mathrm{a}}$ expressed in $\mathrm{U}$ is plotted against the inverse of the prothrombinase activity expressed in 0 .

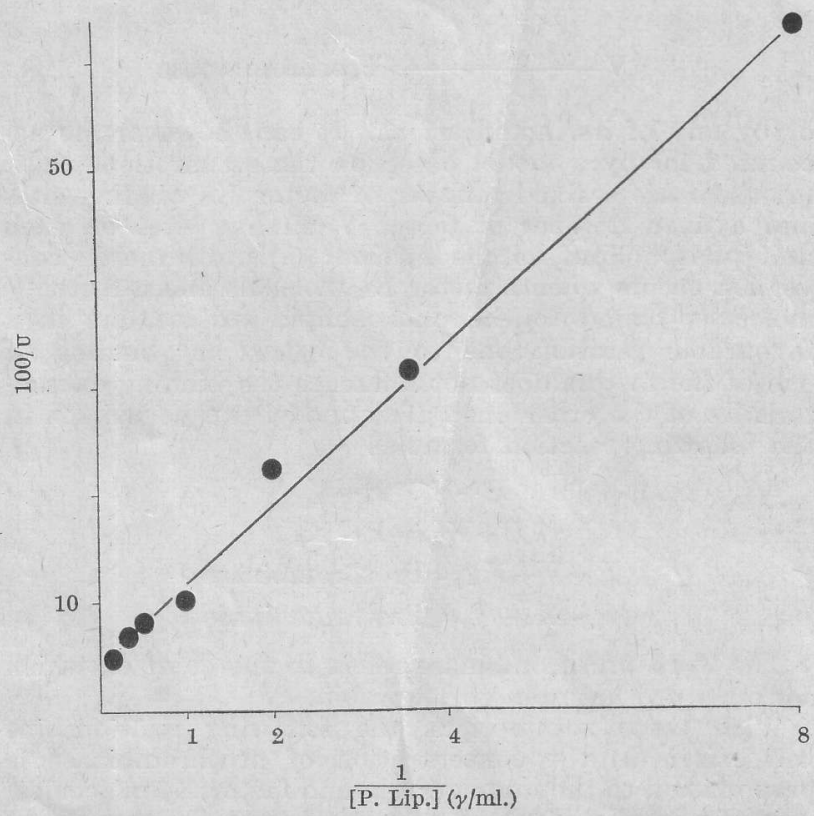

Fig. 5. Kelation between phospholipid and prothrombinase activity. The inverse of the phospholipid concentration expressed in $\gamma / \mathrm{ml}$. 
(b) the concentration of prothrombinase is proportional to the amount of phospholipid surface. This is written in a formula

$$
C=K \cdot P \cdot \frac{P \sim \mathrm{X}}{P} \cdot \frac{P \sim \mathrm{V}}{P}=\frac{K}{P} \cdot P \sim \mathrm{X} \cdot P \sim \mathrm{V}
$$

Where $C$ is prothrombinase concentration; $P$ is phospholipid concentration; $P \sim \mathrm{X}$ is phospholipid bound factor $\mathrm{X}_{\mathrm{a}}$ concentration; $P \sim \mathrm{V}$ is phospholipid bound factor $\mathrm{V}$ concentration, and $K$ is a constant. With the aid of elementary mathematics it can be shown

$$
\begin{aligned}
& \text { from } P+\mathrm{X} \underset{k_{-1}}{\stackrel{k_{+1}}{\rightleftharpoons}} P \sim \mathrm{X} ; k_{-1} / k_{+1}=K^{\prime} \\
& \text { that } \frac{1}{P \sim \mathrm{X}}=\frac{1}{\mathrm{X}}+\frac{1}{P}+\frac{K^{\prime}}{\mathrm{X} \cdot P} \text { and } \\
& \text { from } P+V \underset{k_{-2}}{\stackrel{k_{+2}}{\rightleftharpoons} P \sim V ; k_{-2} / k_{+2}=K^{\prime \prime}} \\
& \text { that } \frac{1}{P \sim V}=\frac{1}{V}+\frac{1}{P}+\frac{K^{\prime \prime}}{V \cdot P}
\end{aligned}
$$

So that $\frac{1}{C}=\frac{P}{K}\left(\frac{1}{\mathrm{X}}+\frac{1}{P}+\frac{K^{\prime}}{\mathrm{X} \cdot P}\right) \cdot\left(\frac{1}{\mathrm{~V}}+\frac{1}{P}+\frac{K^{\prime \prime}}{\mathrm{V} \cdot P}\right)$

In these equations $P, \mathrm{X}$ and $\mathrm{V}$ indicate the total concentrations of phospholipid, factor $\mathrm{X}_{\mathrm{a}}$ and factor $\mathrm{V}$, respectively. For the two protein factors this formula accounts for the relations found: $1 / C$ is linearly proportional to $1 / V$ at fixed $V$ and $P$ concentrations and linearly proportional to $1 / \mathrm{V}$ at fixed $\mathrm{X}$ and $P$ concentrations.

When the relationship between $C$ and $P$ is examined the formula is best written in the form

$$
\frac{1}{C}=P+\frac{1}{P}\left(\mathrm{X}+K^{\prime}\right)\left(\mathrm{V}+K^{\prime \prime}\right)+\left(\mathrm{V}+\mathrm{X}+K^{\prime}+K^{\prime \prime}\right) \frac{1}{\mathrm{XV} K}
$$

At small concentrations of phospholipid $P$ will become negligible compared with $\frac{1}{P}\left(\mathrm{X}+K^{\prime}\right)\left(\mathrm{V}+K^{\prime \prime}\right)$ and the formula will reduce to

$$
\frac{1}{C}=\frac{1}{P}\left(\mathrm{X}+K^{\prime}\right)\left(\mathrm{V}+K^{\prime \prime}\right)+\left(\mathrm{V}+\mathrm{X}+K^{\prime}+K^{\prime \prime}\right) \frac{1}{\mathrm{XV} K}
$$

which accounts for the relationship which we found.

At large concentrations of phospholipid the formula will reduce to

$$
\bar{l}=P+\left(\mathrm{V}+\mathrm{X}+K^{\prime}+K^{\prime \prime}\right) \frac{1}{\mathrm{VXK}}
$$


which predicts the inhibiting effect of excess phospholipid that is often found.

This inhibitory action of excess phospholipid is not seen in the experiments shown in Fig. 5, because the range of phospholipid tested does not include the pertinent concentrations.

From these results it can be soen that near maximal velocity is often found at relatively small concentrations of the three reactants. This finding explains many of the reports in the literature, stating that further addition of one particular reactant did not increase the final yield of prothrombinase. The conclusion that this reactant may not therefore be a constituent of prothrombinase is apparently not justified.

The present investigations have partly been carried out under the auspices of the Netherlands Foundation for Chemical Research (SON) and with financial support from the Netherlands Organization for the Advancement of Pure Research (ZWO). We thank Mr P. P. Devilee for technical assistance.

Received May 8, 1967.

${ }^{1}$ Macfarlane, R. G., Nature, 202, 498 (1964).

2 Davie, E. W., and Ratnoff, O. D., Science, 164, 1310 (1964).

${ }^{3}$ Breckenridge, R. T., and Ratnoff, O. D., J. Clin. Invest., 44, 302 (1965).

- Jobin, F., and Esnouf, M. P., Biochem. J., 102, 666 (1967).

5 Denson, K. W. E., The Use of Antibodies in the Study of Blood Coagulation, 2 (Blackwell Scientific Publications, Oxford, 1967).

6 Esnouf, M. P., and Jobin, F., Biochem. J., 102, 660 (1967).

7 Esnouf, M. P., and Williams, W. J., Biochem. J., 84, 62 (1962).

8 Williams, W. J., and Esnouf, M. P., Biochem. J., 84, 62 (1962).

9 Yin, E. T., Thromb. Diath. Haem., 12, 307 (1964).

${ }^{20}$ Schwert, G. W., and Takenaka, Y., Biochim. Biophys. Acta, 16, 570 (1965). 